\title{
GIS \& SATELLITE DETECTION ANALYSES OF FOREST BELT IN PROKUPLJE MUNICIPALITY
}

\author{
Aleksandar Valjarević, Dragica Živković
}

Original scientific paper

Corine Satellite Detection in combination with GIS may analyse and show the quantitive and qualitive features of a forest belt. As a result, it gives $100 \mathrm{~m}$ resolution satellite recordings and may even show horizontal forest dispersness. In order to avoid exceptions and recording overlapping with digitalization, what is considered is a $100 \mathrm{~m}$ resolution, an identical projection file called WGS 84, so that the Corine recording projection may be harmonised. This detection defines 44 types of earth layers, while a forest earth layer is defined by 12 types of soil. Concerning the specific nature of the territory observed , 5 types of soil are considered. What is observed in the soil structure are features of a territorial span with 3 types of forests, mixed forests, broad-leaved forests and coniferous forests, including two soil types containing sparsely vegetated areas or natural grasslands.

Keywords: analyses; Corina; forest belt; GIS; satellite detection; sub-pixels

Analize šumskog pojasa općine Prokuplje primjenom GIS \& satelitske detekcije

Izvorni znanstveni članak

Corine satelitska detekcija u kombinaciji s GIS-om može analizirati i pokazati kvantitativna i kvalitativna obilježja šumskog pojasa. Kao rezultat, dobivaju se satelitske snimke razlučivosti 100 m, a može se prikazati i horizontalna šumska rasprostranjenost. Kako bi se izbjegle iznimke i preklapanje snimki s digitalizacijom, koristi se rezolucija $100 \mathrm{~m}$, identična projekcijska datoteka pod nazivom WGS 84, tako da se projekcija Corine snimki može uskladiti. Definirane su 44 vrste slojeva zemlje, dok je šumski sloj definiran s 12 tipova tla. S obzirom na specifičnu prirodu promatranog teritorija, razmatrano je 5 vrsta tla. Ono što je promatrano u strukturi tla su značajke površine s 3 vrste šuma, mješovite šume, širokolisne šume i crnogorične šume, uključujući i dva tipa tla koji sadrže slabo obrasla područja ili prirodne travnjake.

Ključne riječi: analiza; Corina; GIS; satelitska detekcija; sub-pikseli; šumski pojas

\section{Introduction}

The knowledge of a single parameter seems insufficient when it comes to calculating a precise analysis. Modern geo spatial observing technologies, along with a GIS analysis and GIS sofware, have come to replace the traditional observing methods of a determined geo space [1].

The Municipality of Prokuplje is located in southern Serbia and it embraces the territory of $758,5 \mathrm{~km}^{2}$. Observing this territory is an interesting matter because the municipality has a geographic position making it the central one in the Toplica region [2]. By involving forest land monitoring, five types of forest soil are taken into consideration [3].

The forest belt becomes visible in three forest types, as broad-leaved, coniferous and the mixed type. The remaining two belts are observed as two soil types, as natural grassland and sparsely vegetated land. By using Global Mapper v 14xx software, Bluemarblegeo.com 2013 Global Mapper 14.

It is a texture over a digital elevation model that is created. In order to create an even more precise 3D model suitable for modelling and obtaining a database, Geo Media professional 16, Intergraph.com is used. In this way a forest belt grid is obtained too [4]

Digital areas are in the whole territory of Prokuplje Municipality. By using a digital elevation model, these can be placed into categories according to Corine mapping methodology. Five types of earth layers are extracted from the entire area. The total degree of forested areas is derived by summing up the area in relation to the entire area cover, also by using the function of a subpixel analysis [5] (Fig. 1).

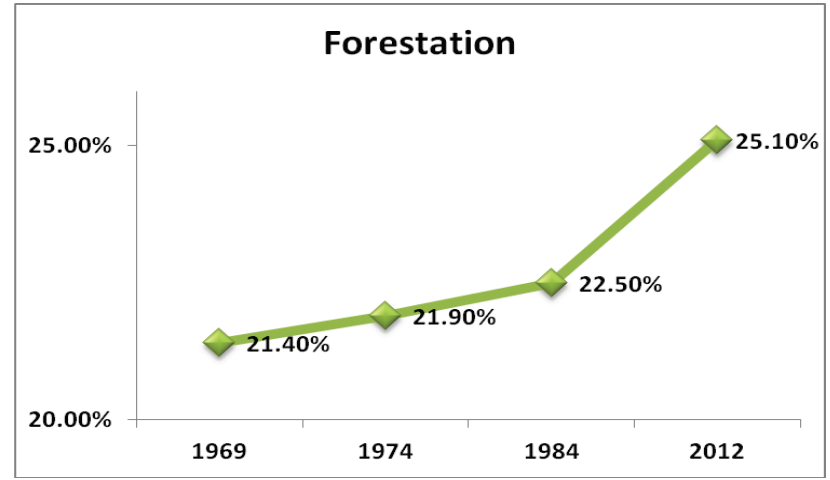

Figure 1 Forestisation in period $1969 \div 2012$ for three types of forest: leaved, conifirous, mixed, comparison with Prokuplje Municipality data 1969, 1974, 1984, 2012).

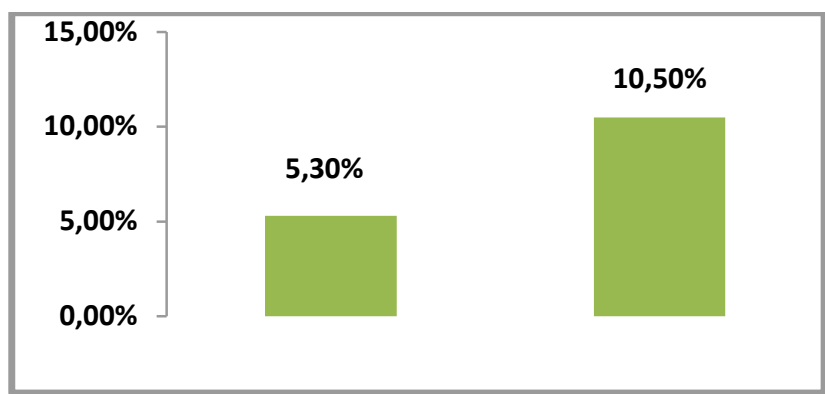

Figure 2 Sparsely vegetated area and natural grassland in CORINE detection on area of Prokuplje Municipality $A=758,3 \mathrm{~km}^{2} \sum=100 \%$.

The two remaining soil types, natural grassland and sparsely vegetated land, are presented with the 2012 data over a Corine satellite detection since the data in the municipality database have not been archived since 1969 . Then, by using Geo Media Professional 6.1 software, in the very software basis of the function vector format, as well as with the use of Add Thematic Legend Entry 
function, five areas are modelled and then displayed in percentage, Fig. 2.

On defining soil topology, according to Corine satellite detection methodology, vector data are selected after having been made digital. [6]. The entirely observed Prokuplje Municipality territory is cropped in Global Mapper 14 software. By means of a pixel analysis, area forest belt features are examined (broad leaved forests, mixed forests, coniferous forests, natural grasslands, sparsely vegetated areas). It is the use of a DEM that determines the horizontal level of a forest belt.

\subsection{Study area}

The municipality of Prokuplje is situated in southeastern part of Serbia, in the Toplica region, in a valley and mountainous parts of the central Toplica basin, between $43^{\circ} 00^{\prime}$ and $43^{\circ} 24^{\prime}$ of northern geographic latitude and $21^{\circ} 24^{\prime}$ and $21^{\circ} 35^{\prime}$ of eastern geographic longitude. It embraces a territory of $758,3 \mathrm{~km}^{2}$. A thoroughfare corridor and the Belgrade-Niš-Priština railway line pass through the municipality territory, including six regional roads, having it connected with the nearby places. The distance from the city of Niš is 27 kilometres, around 50 kilometres from Leskovac, as the one from Belgrade is 250 kilometres.

A favourable geographic position and the field configuration have made it possible for the most important Central Balkans Transversal, connecting the Black Sea with the Adriatic, to partly run through the very Toplica region, across Kosovo and Metohija, creating the shortest connection between the Vardar -Morava valley and the Adriatic. The very road is of a premium importance in terms of entire historic, economic and cultural guidelines. The biggest settlements, including Prokuplje itself, have developed in the valley part of the Toplica River, including the valley of its tributaries, while the mountainous terrains of Veliki Jastrebac Mountain to the north and Radan Mountain along with its slopes to the south surround the space of Prokuplje Municipality.

There are 48501 inhabitants in the 107 settlements of the municipality according to the 2002 population census. About $57 \%$ of the entire population lives in the very town. There are 104 cadastre municipalities with 97 place communities, with the average of 466 inhabitants per settlement. The biggest population is in the settlement of Prokuplje with 27673 inhabitants, and the smallest population is present in the settlement of Jovine Livade with a population of 11 . In the time span between the two censuses, some settlements had been entirely forsaken, with zero inhabitants (New spatial plan of Prokuplje Municipality 2010).

Due to particular factors affecting forest coverage, it is up to a satellite detection to show the real state, including forest frequency and their position in relation to other soil types which are observed in the territory [7].

\section{Materials and method}

The methods used in the territorial analysis become digital on doing a vector raster from a Corine satellite recording and on doing a subpixel SWOT analysis, so that the final digitalised data are obtained from Geo Media
Professional 6.1 with GIS software and Global Mapper 14. The standard Corine methodology earth layer mapping is based upon the data of topographic maps, aero photo recordings, theme maps and field checks. The very methodology is based upon the analysed object characteristic recognition, including colour, structure, texture, patterns and other object relations whose objects of interest are in the very recording [8].

The mapping result is an incessant vector data set with polygon topology. The data may be presented in the format of a raster too. The basic source of mapping has been derived from the orthorectified LANDSAT TM/ETM recordings in the national coordinate system.

The recordings mainly coincide with the referential mapping year with the tolerated exception of one year. The element proportion is 100 metres. The minimal mapping unit is 25 ha, the minimum linear element width is 100 metres. The mapping ratio is $1: 100000$, having been chosen on account of the pan European date base coverage and the fact that this stands for the basic ratio of topographic mapping, being standard in the majority of European countries, including the advantages concerning different environmental projects.

The ratio makes way to updating in a comparatively easy manner on a regular basis. The mapping unit equals the area cover of homogenous earthly layer or a set of smaller homogenous areas representing the more complex structure of an earth layer [9]. The mapping unit should be well recognized in relation to the nearby units and stable enough in temporal sense. The minimum 25 ha mapping unit fits the ratio of 1:100 000. The linear element width unit of 100 metres equals 1 mille metres in the ratio of mapping. The Corine nomenclature has been viewed in the 1993 Corine Land Cover Technical Guide [10]. That is the physical and the physiognomic nomenclature of the earth layer relevant to environmental monitoring. The three forest belt types are observed. These are deciduous forests, mixed type forests and coniferous forests. By doing a SWOT analysis, the total of forested areas is determined, including the average density of the forest belt, Eq. (1), Tab. 1.

$A_{i}=\sum_{j=1}^{n} \lambda_{i j} \cdot z\left(u_{j}\right)$.

Table 1 Types of land in territory of Prokuplje

\begin{tabular}{|l|r|r|}
\hline Agro-forestry areas & $10,3 \%$ & $78,12 \mathrm{~km}^{2}$ \\
\hline $\begin{array}{l}\text { Annual crops associated with } \\
\text { permanent crops }\end{array}$ & $19,2 \%$ & $145,59 \mathrm{~km}^{2}$ \\
\hline Broad leaved forest & $21,5 \%$ & $163,03 \mathrm{~km}^{2}$ \\
\hline Coniferous forest & $1,5 \%$ & $11,38 \mathrm{~km}^{2}$ \\
\hline Constructions sites land & $0,3 \%$ & $2,27 \mathrm{~km}^{2}$ \\
\hline $\begin{array}{l}\text { Land principally occupied by } \\
\text { agriculture }\end{array}$ & $28 \%$ & $212,33 \mathrm{~km}^{2}$ \\
\hline Mixed forest & $2,1 \%$ & $15,92 \mathrm{~km}^{2}$ \\
\hline Natural grassland & $10,5 \%$ & $78,87 \mathrm{~km}^{2}$ \\
\hline Sparsely vegetated area & $0,3 \%$ & $39,43 \mathrm{~km}^{2}$ \\
\hline Vineyards & $0,7 \%$ & $2,27 \mathrm{~km}^{2}$ \\
\hline $\begin{array}{l}\text { Road and rail networks with } \\
\text { associated land }\end{array}$ & $0,2 \%$ & $5,30 \mathrm{~km}^{2}$ \\
\hline River Toplica & $0,3 \%$ & $1,51 \mathrm{~km}^{2}$ \\
\hline Water Bodies-Likes & $100 \%$ & $758,30 \mathrm{~km}^{2}$ \\
\hline Total Sum & \multicolumn{2}{|l}{} \\
\hline
\end{tabular}




\subsection{Sub pixel analysis of forest belt}

The reflection calculated in a Corine satellite recording, measured for one pixel, represents the linear combination of individual reflection phenomena that participate in the contents of a homogenous pixel. The exact knowledge of individual pixel reflection is important in terms of obtaining pixel phenomena frequency[11]. The potential hardship may lie in recording refrection liable to variations in relation to versatile bio physical phenomena. Forest vegetation reflection clearly depends on the optic features of a vegetational tissue, vegetation structure and the eco system [12]. The method of pixel dismemberment into sub pixels is a two-segment unit; it includes a soft classification and sub -pixel mapping. The soft method task lies in obtaining the information on the inside of mixed-pixel percentage which represents forest vegetation. The sub pixel- mapping must locate the fractions and draw a line among different forest vegetation. As a soft classification method, a specially designed unmixing partial model has been applied. For the selection of sub pixel mapping a pixel swapping algorithm has been applied too. In order to apply the linear unmixing method, one should start from a linear model of spectral blending for the very method to become complete. All the phenomena and their spectres present in a Corine recording should be recognised in the first place, as their number must be smaller or equal to the number of spectrum recording channels.

It often seems difficult to cause this reality because even the smallest disorders will cause big errors in the soft classification [13]. A soft classification result is the percentage frequency of a phenomenon in every pixel. What is done next is the determination of soft classification results representing the percentage of phenomena frequency in every pixel. It is a location method of sub-pixel components in the very pixel that is in use. The algorithm which determines the percentage of forest belt frequency for all three soil types covered in forests in relation to the two soil types having no forest belt is called a pixel swapping algorithm.The original pixel spatial resolution is divided into $16(4 \times 4)$ pixels. The algorithm has been based upon a geostatic method for pixel classification. Each forest belt subpixel calculates a belonging parameter $A_{i}$. This changeable unit represents an inclination percentage function for the frequency of a phenomenon, as well as the homogenous forest soil areas of the remaining pixels. The model is shown in Eq. (2). Including the percentrage of frequency phenomena of pixel $\mathrm{j}$, while $\lambda_{i i}$, stands for the weight which depends on the pixel distance (Eq. (2)).

$$
\lambda_{i j}=\exp \left(\frac{-h_{i j}}{a}\right)
$$

$h_{i j}$ - represents the distance between the subpixel $(i)$, which calculated by the belonging stands for the parametar and the adjacent pixel in location $(j),(a)$ stands for the non-linear model of the exponential model. Every original pixel is defned by the number of subpixels belonging to the phenomenon observed of area $(k)$. In this way $(k)$ subpixels within the original pixel, in this case the Corine recording forest belts of the highest belonging parametar value, are determined as belonging to the phenomenon (Fig. 3).

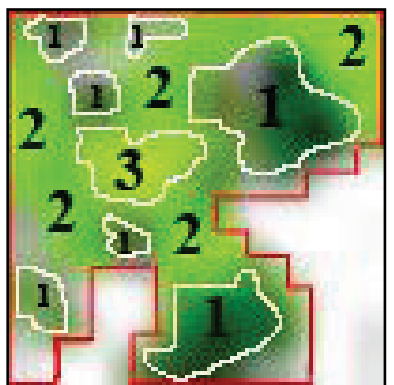

Figure 3 Sub pixels analyses of forest belt: 1 - Coniferous forest, 2 Broad leaved forest, 3 - Natural grassland

A special matrix determines the number of pixels within the Corine recording defining the forest phenomenon in the recording.

\section{Materials and method}

The result which comes as a result of raster data digitalisation, including the sub-pixel analysis of a Corine satellite recording, gives way to viewing the geo spatial data in the way that follows the changes of natural resources and particular territory laws. The territory of Prokuplje Municipality is observed in the light of Corine satellite recording monitoring in the ratio of 1:100 000 . Digital data make a geo spatial analysis easier.

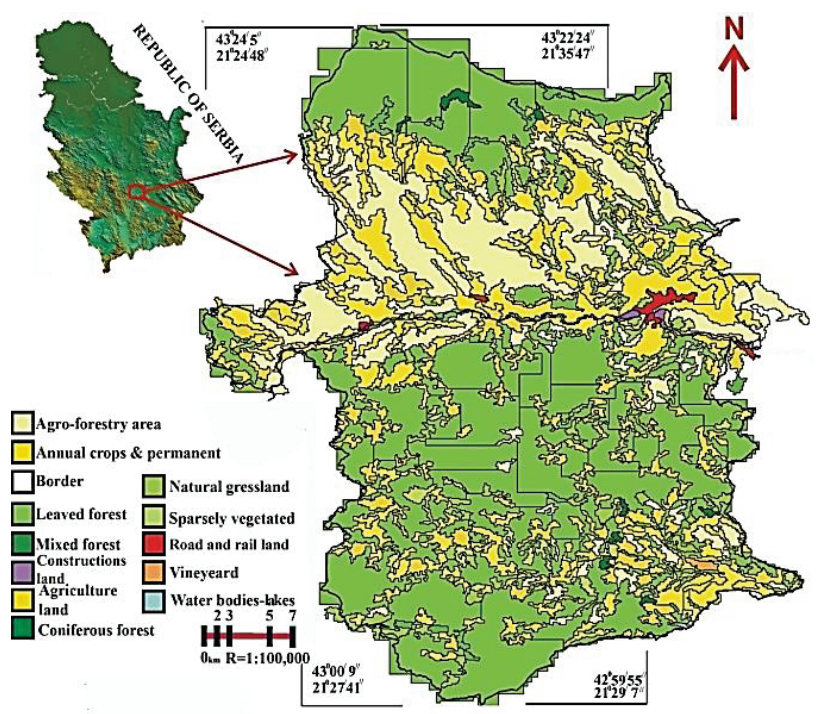

Figure 4 Map of forestry land and other category lands with help of CORINE mapping terminology on the Prokuplje Municipality 2012

By using Corine satellite nomenclature, what is observed is a natural phenomena change, primarily the one of forest land in proportion to the entire area of the territory observed. A sub-pixel analysis, along with the method of recording integration, enables the selection of three forest types, including the mixed type, broad leaved forest, and coniferous, also involving the remaining two types of soils related to the previous forest land; these are natural grassland and sparsely vegetated areas [15]. This is the way in which all type soils with a forest belt are obtained, expressed by a $\mathrm{m}^{2}$ and percent. The total forest 
belt covered in Prokuplje Municipality is $25,10 \%$ or $190,6 \mathrm{~km}^{2}$. The remaining land area cover is $15,8 \%$ or $118,3 \mathrm{~km}^{2}$. These are the areas which stand for digitilised data. The data now, in the form of a vector, can be exported into GIS softwares. In this way, the entire area monitoring is obtained with a view of Prokuplje Municipality and the perception of the forest belt in it. This is of great importance for the further forest belt prognosis, as well as the percentage belt participation in relation to some other land Fig. 4.

\section{Conclusion}

The total of $3,70 \%$ forest increase indicates that forests are returning to their initial habitats, where they were prior to 1969 . Of the entire forest areas dealt with by monitoring and through the digitalisation of the 2012 Corine recording, what could be noticed is that the greatest change has occured with mixed type areas, with this type of forests being mostly along agricultural forest lands. The percentage of the soils which represent natural grasslands and sparsely vegetated areas is comparatively big in terms of the entire area observed, which indicates that the forest belt has been exposed to degradation which has ceased and that the forests are slowly recovering from cutting because the municipality is an exlusive place. The 1:10 000 map, Fig. 4, displays the meta vector data of a forest belt in relation to other types of land in accordance with Corine mapping methodology. Satellite controlled detection, along with a sub-pixel analysis, including GIS as well, may represent in the future a very solid basis for observing the macro and the micro regions alike [16]. Data modelling shown in the map is of great importance as the data then pick up plasticity, so that the potential user may have an insight into a practical territory observation.

\section{Acknowledgment}

This work was financially supported by the Serbian Ministry of Education and Science project III44006, and also for project No. 176019.

\section{References}

[1] De Mers, M. N. Fundamentals of Geographic Information Systems. $3^{\text {rd }}$ ed. Wiley, New York, 2005.

[2] Rudic, V. Population of city Prokuplje, Master Thesis, Belgrade, 1972.

[3] Watson, G. A. Development of Mixed Tree and Food crops Systems in the Humid, 2008

[4] Zhang, W.; Montgomery, D. Digital elevation model grid size, landscape representation, and hydrologic simulation. // Water Resources Research. 30, 4(1994), pp. 1019-1028. DOI: 10.1029/93WR03553

[5] Perdigao, V.; Annano, A. Technical and methodological guide for updating CORINE Land Cover Data Base. JRC/EEA, 1997.

[6] Heyman, Y.; Steemans, C.; Croissille, Ch.; Bossard, M.G. CORINE Land Cover. Technical Guide, EUR 1258 Luxemburg, Office for Official Publications of the European Communities, 1994.

[7] Foote, A. L.; Pandey, S. Understanding poetry. $3^{\text {rd }}$ ed. New York : Holt, Rinehart and Winston, 1960.
[8] Michael, B.; Yichum, X. Modeling inside GIS: Selecting and Celebrating Urban models using ARC-Info. // International Journal of Geographic Information Science. 8, 5(2001), pp. 457-470.

[9] Lillesand, T.; Kiefer, R. Remote sensing and image interpretation, Wiley, New York, 1979.

[10] Bossard, M.; Feranec, J.; Otahel, J. CORINE Land cover technicalGuide Addendum 2000, Technical report No 40 EEA, Copenhagen, 2000.

[11] Tompkins, S.; Mustard, J. F.; Pieters, C. M.; Forsyth, D. W. Optimization of End members for Spectral Mixture Analyses. // Remote Sensing and Environment. 59, 2(1997), pp. 472-489. DOI: 10.1016/S0034-4257(96)00122-8

[12] Asner, G. P. Biophysical and Biochemical Sourcesof Variability in Canopy Reflectance. // Remote Sensing and Environment. 64, 3(1998), pp. 234-253. DOI: 10.1016/S00344257(98)00014-5

[13] Muslims, A. M.; Foody, G. M.; Atkinson, P. M. Localized soft classification for super-resolution mapping of the shoreline. // International Journal of Remote Sensing. 27, 2(2006), pp. 2271-2285. DOI: 10.1080/01431160500396741

[14] Chang, T. C. Multi-Component Quantitative Mapping. // The Cartographic Journal. 19, 2(1982), pp. 95-103. DOI: 10.1179/caj.1982.19.2.95

[15] Qiang, Y.; Dalafontaine, M.; Tijs, N.; Birger, S.; Guy, T.; Nico, W. Analysing Imperfect Temporal, Information in GIS Using the Triangular Model. // The Cartographic Journal. 49, 3(2012), pp. 265-280. DOl: 10.1179/1743277412Y.0000000008

[16] Macdonald, L. H.; Anderson, D. A.; Dietrich, W. E. Paradise Threanaded: Land Use and Erosion on St. John, US Virgin Islands. // Environmental Management. 21, 6(1997), pp. 851-863. DOI: 10.1007/s002679900072

[17] Software Global Mapper V14 xx

[18] Software GeoMedia Professional 6.1

\section{Authors' addresses}

Aleksandar Valjarević, Assoc. prof. PhD

University of Kosovska Mitrovica,

Faculty of Natural Science and Mathematics,

Department of Geography,

Lole Ribara 29, 38220 Kosovska Mitrovica, Serbia

Contact: +38128425396, aleksandar.valjarevic@pr.ac.rs

Dragica Živković, Full prof. PhD

University of Belgrade, Faculty of Geography, Studentski trg 3/III, 11000, Belgrade, Serbia Contact: +381112637421, dragica@gef.bg.ac.rs 